\title{
PENERAPAN TEKNOLOGI PEMBUATAN PUPUK ORGANIK DALAM PENGOLAHAN LIMBAH PASAR MARDIKA AMBON
}

\author{
${ }^{1}$ Nur Alim Natsi, ${ }^{2}$ Chaldun Kilwouw, ${ }^{3}$ Salim \\ ${ }^{1}$ Program Studi Pendidikan Biologi, IAIN Ambon \\ ${ }^{2,3}$ Mahasiswa Program Studi Pendidikan Biologi, IAIN Ambon \\ ${ }^{1}$ E-mail: nuralimnatsir@gmail.com
}

\begin{abstract}
Abstrak: Permasalahan pengelolaan sampah juga merupakan masalah pelik yang dihadapi oleh warga di sekitar Pasar Mardika, yang terletak di Batu Merah Kecamatan Sirimau Kota Ambon. Volume timbunan sampah hasil pemilahan sayur dan buah-buahan di sekitar Pasar Mardika dapat mencapai 3 (tiga) $\mathrm{m}^{3}$ setiap harinya, sehingga hal ini berdampak terhadap pencemaran lingkungan. Solusi yang dilakukan untuk mengatasi masalah tersebut adalah dengan mengkonversi sampah organik menjadi pupuk padat dan cair dengan menggunakan EM4 sebagai biang aktivator. Hasil penelitian menunjukkan bahwa pupuk organik padat dan cair memiliki sifat fisik yang baik dan mengandung $\mathrm{N}$, $\mathrm{P}$, dan $\mathrm{K}$ yang cukup tinggi sehingga sangat baik diterapkan dalam dunia pertanian dan aman bagi lingkunga.
\end{abstract}

Kata Kunci: Sampah, Pasar Mardika, EM4

\section{APPLICATION OF TECHNOLOGY THE MANUFACTURE OF FERTILIZERS ORGANIC MATTER IN WASTE PROCESSING MARKET MARDIKA AMBON}

\begin{abstract}
: problems waste management is also a major problem faced by the mardika around the market, located in a red stone sirimau in Ambon city. The volume of garbage sorting the vegetable and fruits in mardika around the market can reach $3 \mathrm{~m}^{3}$ every day, so it had an impact on environmental pollution. A solution was done to deal with the issue was by converting organic waste into solid and liquid fertilizer using $\mathrm{EM}_{4}$ activator a source of. The result showed that organic fertilizers a solid and a liquid having the physical properties of good and contain $\mathrm{N}, \mathrm{P}$, and $\mathrm{K}$ are high and thus are properly applied in the world of agriculture and safe for enviromental
\end{abstract}

\section{Keywords: Garbage, Mardika Market, $\mathrm{EM}_{4}$}

Sampah merupakan permasalahan utama yang dapat ditemukan hampir di semua pasar tradisional di Indonesia. Selama ini sebagian besar pasar tradisional dalam mengelola 
sampah masih bertumpu pada pendekatan akhir (end of pipe), yaitu sampah dikumpulkan, diangkut, dan dibuang ke tempat pemrosesan akhir sampah (TPA). Hal ini berpotensi besar melepas gas metan $\left(\mathrm{CH}_{4}\right)$ yang dapat meningkatkan emisi gas rumah kaca dan memberikan kontribusi terhadap pemanasan global. Selain itu juga diperlukan biaya yang tidak sedikit untuk mengangkut sampah tersebut ke TPA (Nan Djuarnani, Kristian dan Budi Susilo Setiawan, 2006). Permasalahan pengelolaan sampah juga merupakan masalah pelik yang dihadapi oleh warga di sekitar Pasar Mardika, yang terletak di Batu Merah Kecamatan Sirimau Kota Ambon. Wilayah ini merupakan dataran tinggi ( $\pm 800 \mathrm{~m}$ di atas permukaan laut), yang menghasilkan berbagai komoditas hasil laut dan pertanian.

Pasar Mardika merupakan salah satu pasar pengumpul sayur dan buah terbesar di Ambon. Setelah proses jual-beli dengan petani, para pedagang pengumpul akan melakukan pemilahan, dan membuang bagian yang tidak layak jual di seputaran pasar. Masalah yang terjadi adalah semakin menggunungnya tumpukan sampah yang mengganggu estetika perkampungan, dan menimbulkan bau menyengat bagi warga sekitar. Masalah ini semakin diperparah karena Pasar Mardika terletak kurang-lebih 5 kilometer di sebelah barat Ibu Kota, sehingga peranan Dinas Pekerjaan Umum Perhubungan dan Kebersihan (DPUPK) Ambon dalam menanggulangi masalah sampah menjadi tidak maksimal. Volume timbunan sampah hasil pemilahan sayur dan buahbuahan di sekitar Pasar Mardika dapat mencapai 3 (tiga) $\mathrm{m}^{3}$ setiap harinya, sehingga hal ini berdampak terhadap pencemaran lingkungan.

Pupuk organik padat adalah salah satu jenis pupuk yang aman dan cocok digunakan untuk jenis tanaman apa saja, selain aman bagi tanaman, juga aman terhadap lingkungan karena tidak mengandung residu zat kimia yang dapat membahayakan keseimbangan lingkungan. Sekarang ini, di Negara-negara maju, telah dikampayekan bahkan digunakan pupuk organik, dan menghentikan penggunaan pupuk anorganik sintetis. Perhatian yang cukup besar ini, mendorong pertumbuhan usaha-usaha dan industri-industri pertanian untuk berlomba-lomba dalam menciptakan formula pupuk organik yang aman bagi tanaman, masyarakat, dan lingkungan. Terdapat dua macam pupuk organik yaitu pupuk organik padat dan organik cair. Pupuk organik padat merupakan pupuk organik yang berasal dari sisa tanaman, kotoran hewan, dan kotoran manusia yang berbentuk padat sedangkan pupuk organik cair merupakan larutan yang berasal dari pembusukan bahan-bahan organik. Kelebihan pupuk organik cair adalah mampu memberikan hara bagi tanaman tanpa merusak unsur hara di dalam tanah dan lebih mudah diserap oleh tanaman (Honcamp, F, 1931).

Salah satu teknologi pembuatan pupuk organik yang telah dkembangkan dan disosialisasikan oleh Instalasi Penelitian dan Pengkajian Teknologi Pertanian adalah teknologi fine compost (Redaksi Agromedia, 2008). Pada dasarnya, teknologi ini ditujukan untuk mempercepat proses pembuatan kompos (matang dalam waktu 3 minggu), dan sekaligus meningkatkan kualitas kompos yang dihasilkan (Macdonald, 
1989). Teknologi ini cukup sederhana, dan bahan-bahan yang diperlukan juga sangat mudah didapatkan di sekitar Pasar Mardika. Oleh karena itu, melalui Program Penelitian Berbasis Masyarakat (PPBM) diharapkan permasalahan sampah di Pasar Mardika dapat diselesaikan sekaligus dimanfaatkan menjadi pupuk organik yang dapat membantu untuk mencukupi kebutuhan pupuk masyarakat setempat, ataupun dikemas sebagai komoditas yang memiliki nilai jual.

\section{METODE PENELITIAN}

Penelitian ini merupakan eksperimen laboratorium yang bertujuan untuk mengetahui cara pembuatan pupuk kompos berbahan dasar limbah organik pasar dan mengetahui kualitas fisik (warna, keremahan, dan suhu akhir fermentasi) dan kualitas kimia (N, P, dan K) pupuk kompos cair dan padat yang diproduksi dengan menggunakan limbah organik pasar. Penelitian ini dilaksanakan selama 3 bulan yang terhitung mulai bulan Juni-Agustus 2016 yang berlokasi di 3 tempat yaitu: pengambilan limbah organik di pasar Mardika Ambon, Pembuatan pupuk kompos dan pengujian fisik dilakukan di laboratorium MIPA IAIN Ambon, dan pengujian kandungan N, P, dan K di laboratorium Kimia UMM Malang.

Obyek dalam penelitian ini adalah peningkatan kadar N, P, dan K pupuk kompos padat dan cair berbahan dasar limbah organik dari pasar Mardika dengan menggunakana variasi konsentrasi EM4. Selain kadar N, P, dan K, dalam penelitian ini diukur kualitas fisik dari pupuk kompos yang dihasilkan yang meliputi: suhu, warna, dan aroma. Variabel dalam penelitian ini adalah konsentrasi EM4 sebagai variabel bebas dengan 5 taraf yaitu $(5 \%, 10 \%, 15 \%, 20 \%$, dan 25\%) dan kadar N, P, dan K dalam satuan ppm sebagai variabel terikat. Pembuatan pupuk kompos dimulai dengan cara mengumpulkan limbah organik pasar berupa potongan sayur dan buah busuk lalu ditimbang sebanyak $10 \mathrm{~kg}$. limbah orgnik yang telah ditimbang selanjutnya di potong-potong dengan ukuran kecil. Jika memiliki mesin penggiling sampah, maka dapat digunakan untuk menghancurkan limbah organik sehingga mempercepat proses fermentasi.

Menyediakan 5 buah tabung fermentor yang berukuran 5 liter dan mengisi masing-masing tabung dengan $2 \mathrm{~kg}$ limbah. Bagian tengah tabung fermentor diberi lapisan berpori yang berfungsi untuk melewatkan cairan hasil fermentasi (bakal pupuk cair). Membuat konsentrasi EM4 sesuai dengan perlakuan (5\%, 10\%, 15\%, 20\%, dan $25 \%$ ) dan dicampurkan ke dalam tabung fermentor lalu melakukan pengadukan sampai homogen. Tutup tabung fermentor dengan kain goni agar tidak terjadi kontaminasi dan mempercepat proses fermentasi. Setiap seminggu sekali dilakukan pengadukan dan pemeriksaan suhu tabung fermentor selama 5 minggu. Melakukan pemeriksaan waktu pematangan pupuk dan pupuk cair. Melakukan analisis fisik pada pupuk yang dihasilkan meliputi: warna, keremahan, dan suhu akhir fermentasi. Selain analisis fisik, dilakukan pengujian kimia yang meliputi kandungan $\mathrm{N}$ (nitrogen), $\mathrm{P}$ (phosphor), dan K (kalium). 
Data dalam penelitian ini berupa data kuantitatif terkait dengan hasil uji fisik dan kimia dari pupuk padat dan cair yang dihasilkan. Analisis fisik meliputi: suhu, warna, keremahan, dan aroma pupuk, sedangkan analisis kimia meliputi: kadar Nitrogen (N), Phospor (P), dan Kalium (K). Data kuantitatif berupa angka-angka terkait kadar Nitrogen $(\mathrm{N})$, Phospor (P), dan Kalium (K) diperoleh melalui pengujian laboratorium dan dianalisis dengan menggunakan uji Anova satu jalur pada taraf signifikan 5\%.

\section{HASIL DAN PEMBAHASAN}

\section{Pengamatan Visual Pupuk Organik Padat}

Limbah organik yang diambil dari pasar Mardika Ambon difermentasi dengan menggunakan EM4 pada konsentrasi 5\%, 10\%, 15\%, 20\%, dan 25\% memperlihatkan kondisi visual yang berbeda. Data hasil pengamatan visual pupuk organik padat dapat dilihat pada Tabel 1 berikut

Tabel 1. Pengamatan Visual Pupuk Organik Padat Berbahan Dasar Limbah Pasar Mardika

\begin{tabular}{|c|l|l|l|l|l|}
\hline \multirow{2}{*}{$\begin{array}{c}\text { Konsentrasi } \\
\text { EM4 }\end{array}$} & \multicolumn{1}{|c|}{$\begin{array}{c}\text { Lama } \\
\text { Fermentasi }\end{array}$} & $\begin{array}{c}\text { Suhu } \\
\text { Akhir }\end{array}$ & Warna & Kondisi Fisik & Keremahan \\
\hline $5 \%$ & 4 minggu & $30^{\circ} \mathrm{C}$ & Coklat tua & Partikel agak halus & Agak Remah \\
\hline $10 \%$ & 4 minggu & $28^{\circ} \mathrm{C}$ & Coklat tua & Partikel agak halus & Aga Remah \\
\hline $15 \%$ & 4 minggu & $27^{0} \mathrm{C}$ & Coklat tua & Partikel agak halus & Remah \\
\hline $20 \%$ & 3 minggu & $27^{\circ} \mathrm{C}$ & Hitam & Partikel agak halus & Remah \\
\hline $25 \%$ & 2 minggu & $27^{\circ} \mathrm{C}$ & Hitam & Partikel agak halus & Remah \\
\hline
\end{tabular}

Tabel 1 menunjukkan bahwa konsentrasi EM4 25\% lebih baik dari konsentrasi lainnya dalam hal lama fermentasi, suhu akhir fermentasi, warna, kondisi/ukuran parikel, dan keremahan pupuk organik. Konsentrasi EM4 5\%, 10\%, dan 15\% memberikan hasil yang hampir sama baik dari segi lama fermentasi, suhu akhir fermentasi, warna, ukuran partikel, dan keremahan pupuk organik. Selain mengamati data visual pupuk organik padat, dalam penelitian ini dilakukan pengamatan visual pupuk organik cair yang terlihat pada Tabel 2 berikut

Tabel 2. Pengamatan Visual Pupuk Organik Cair Berbahan Dasar Limbah Pasar Mardika

\begin{tabular}{|c|c|c|c|c|}
\hline \multirow{2}{*}{$\begin{array}{c}\text { Konsentrasi } \\
\text { EM4 }\end{array}$} & \multicolumn{4}{|c|}{ Parameter Ukur } \\
\hline & $\begin{array}{c}\text { Lama } \\
\text { Fermentasi }\end{array}$ & Suhu Akhir & Warna & Aroma \\
\hline $5 \%$ & 4 minggu & $30^{0} \mathrm{C}$ & Coklat & Berbau menyengat \\
\hline $10 \%$ & 4 minggu & $28{ }^{0} \mathrm{C}$ & Coklat & Berbau menyengat \\
\hline $15 \%$ & 4 minggu & $27^{0} \mathrm{C}$ & Coklat & Berbau menyengat \\
\hline $20 \%$ & 3 minggu & $27^{0} \mathrm{C}$ & Coklat tua & Berbau menyengat \\
\hline $25 \%$ & 2 minggu & $27^{0} \mathrm{C}$ & Coklat tua & Berbau menyengat \\
\hline
\end{tabular}


Tabel 2 menunjukkan bahwa konsentrasi EM4 25\% lebih baik dari konsentrasi lainnya dalam hal lama fermentasi, suhu akhir fermentasi, warna, kondisi/ukuran parikel, dan keremahan pupuk organik. Konsentrasi EM4 5\%, 10\%, dan 15\% memberikan hasil yang hampir sama baik dari segi lama fermentasi, suhu akhir fermentasi, warna, dan aroma. Selain mengamati data visual pupuk organik padat dan cair, dalam penelitian ini dilakukan pengukuran kadar N, P, dan K pada pupuk organik padat maupun organik cair yang dapat dilihat pada Tabel 3 berikut

Tabel 3. Kadar N, P. dan K Pupuk Organik Padat

\begin{tabular}{|c|c|c|c|}
\hline \multirow{2}{*}{$\begin{array}{l}\text { Konsentrasi } \\
\text { EM4 }\end{array}$} & \multicolumn{3}{|c|}{ Parameter Ukur dalam ppm } \\
\hline & $\mathrm{N}$ & $\mathrm{P}$ & $\mathrm{K}$ \\
\hline $5 \%$ & 186 & 189 & 638 \\
\hline $10 \%$ & 213 & 201 & 702 \\
\hline $15 \%$ & 237 & 231 & 745 \\
\hline $20 \%$ & 275 & 227 & 7856 \\
\hline $25 \%$ & 286 & 239 & 856 \\
\hline
\end{tabular}

Tabel 3 memperlihatkan kandungan N, P, dan K pada pupuk organik padat dengan perlakuan konsentrasi EM4. Kadar Nitrogen pada tiap perlakuan berbeda-beda dengan nilai N, P, dan K tertinggi pada perlakuan EM4 25\% dan terendah pada perlakuan EM4 $5 \%$. Selain data kandungan N, P, dan K pada pupuk organik padat, dalam penelitian ini juga dianalisis kadar N, P, dan K pada pupuk organik cair yang dapat dilihat pada Tabel berikut

Tabel 4. Kadar N, P. dan K Pupuk Organik Cair

\begin{tabular}{|c|l|l|l|}
\hline \multirow{2}{*}{$\begin{array}{c}\text { Konsentrasi } \\
\text { EM4 }\end{array}$} & \multicolumn{3}{|c|}{ Parameter Ukur dalam ppm } \\
\cline { 2 - 4 } & $\mathrm{N}$ & \multicolumn{1}{|c|}{$\mathrm{P}$} & $\mathrm{K}$ \\
\hline $5 \%$ & 216 & 207 & 675 \\
\hline $10 \%$ & 231 & 231 & 746 \\
\hline $15 \%$ & 276 & 235 & 789 \\
\hline $20 \%$ & 287 & 246 & 846 \\
\hline $25 \%$ & 296 & 259 & 870 \\
\hline
\end{tabular}

Tabel 4 tersebut menunjukkan bahwa pupuk organik cair berbahan dasar limbah sampah dari pasar mardika mengandung nutrisi yang dbutuhkan untuk pertumbuhan tanaman, dalam hal ini adalah nitrogen, posfor, dan kalium. Kadar N, P, dan K tertinggi diperoleh pada perlakuan EM4 konsentrasi 25\% dan kadar N, P, dan K terendah diperoleh pada perlakuan EM4 5\%.

Hasil penelitian tentang kondisi visual pupuk padat dan cair yang dihasilkan setelah proses fermentasi dengan menggunakan EM4 pada konsentrasi 5\%, 10\%, 15\%, $20 \%$, dan $25 \%$ memperlihatkan hasil yang berbeda baik dari lama fermentasi, suhu akhir fermentasi, warna pupuk, dan aroma pupuk. Perbedaan yang timbul disebabkan oleh aktivitas mikroorganisme yang terdapat di dalam EM4 yang terlibat langsung dalam 
memfermentasi bahan organik menjadi unit-unit sederhana. Makin tinggi konsentrasi EM4 yang digunakan dalam memfermentasi bahan organik, maka jumlah mikroorganisme yang ada di dalam EM4 semakin besar, sehingga proses fermentasi akan berlangsung dengan cepat. Suhu akhir fermentasi merupakan salah satu indikator bahwa proses fermentasi berlangsung dengan baik. Diakhir fermentasi suhu akan turun sampai kisaran suhu kamar yang mengindikasikan bahwa pupuk organik yang dihasilkan siap untuk digunakan dan bisa diserap oleh akar tumbuhan.

EM4 merupakan bioaktivator yang mengandung banyak sekali mikroorganisme pemecah bahan-bahan organik. Margaretha dan Itang berpendapat bahwa mikroorganisme dapat meningkatkan penyerapan unsur hara, karena mikroorganisme dapat meningkatkan penyerapan karbohidrat dan beberapa unsur lainnya. Dalam limbah sayur maupun buah terdapat bahan-bahan organik seperti nitrogen (N) untuk pertumbuhan tunas, batang dan daun; fosfor $(\mathrm{P})$ untuk merangsang pertumbuhan akar, buah dan biji; dan kalium (K) untuk meningkatkan ketahanan tanaman terhadap serangan hama penyakit yang dibutuhkan tanaman. Namun tidak dapat langsung diserap oleh tanaman karena masih dalam bentuk senyawa yang perlu dipecah menjadi bentuk ion-ion yang mudah diserap tanaman. Dengan adanya fermentasi, zat-zat tersebut dapat diserap dengan mudah oleh tanaman.

Proses fermentasi limbah sayur dan buah dilakukan selama 14 sampai 28 hari yang berfungsi menguraikan unsur-unsur organik yang ada dalam limbah tersebut sehingga dapat diserap oleh tanaman disekitarnya. Penambahan EM4 berfungsi untuk mengaktifkan bakteri pelarut, meningkatkan kandungan humus tanah sehingga mampu menguraikan bahan organik menjadi asam amino yang mudah diserap oleh tanaman dalam waktu cepat. Bila pupuk yang berasal dari limbah organik dalam bentuk cair disemprotkan dalam tanaman akan meningkatkan jumlah klorofil sehingga akan berpengaruh pada proses fotosintesis pada tanaman. Menurut Koepper, proses fermentasi lebih cepat pada lingkungan kedap udara (anaerob). Fermentasi dapat menghasilkan sejumlah senyawa organik seperti asam laktat, asam nukleat, biohormon, dan lain sebagainya yang mudah diserap oleh akar tanaman. Senyawa organik ini juga dapat melindungi tanaman dari hama penyakit. Reaksi yang terjadi dalam proses fermentasi untuk mendapat hara nitrogen $(\mathrm{N})$ adalah ((Sintha, 2008)

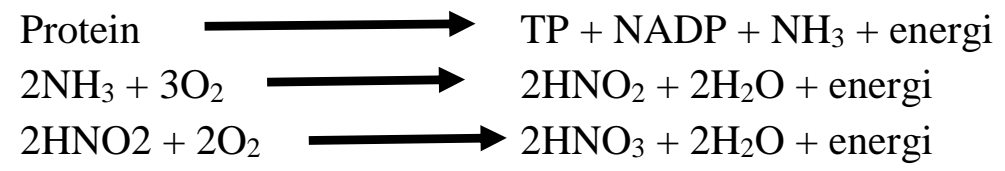

Sedangkan untuk mendapatkan hara fosfor sebagai berikut:

ATP + glukosa $\longrightarrow$ ADP + glukosa 6 fosfat

Glukosa 6-fosfat $+\mathrm{H} 2 \mathrm{O} \longrightarrow$ glukosa + fosfat

Nitrogen yang tidak sempurna diserap oleh akar sehingga keberadaannya dalam tanaman terlalu rendah akan menurunkan aktifitas sitokinin. Turunnya aktifitas sitokinin 
tersebut menyebabkan terganggunya metabolisme protein di daun karena sitokinin akan bertindak sebagai regulator dalam pembentukan senyawa protein tanaman. Sedangkan gugus Nitrogen organik pada glutamat dan glutamin dapat digunakan untuk sintesis amida lain, sebagaimana ureida, asam amino dan senyawa dengan berat molekul (BM) tinggi seperti protein. Nitrogen juga penting sebagai penyusun enzim yang sangat besar peranannya dalam proses metabolisme tanaman, karena enzim tersusun dari protein. Sebagai pelengkap bagi peranannya dalam sintesa protein, Nitrogen merupakan bagian tak terpisahkan dari molekul klorofil dan karenanya suatu pemberian $\mathrm{N}$ dalam jumlah cukup akan mengakibatkan pertumbuhan vegetatif yang vigor dan warna hijau segar (Cattelan, A.J., P.G. Hartel, and J.J. Fuhrmann, 1999).

Dalam pertumbuhannya tanaman memerlukan tiga unsur hara penting, yaitu nitrogen $(\mathrm{N})$, fosfat $(\mathrm{P})$, dan kalium $(\mathrm{K})$. Peranan utama nitrogen $(\mathrm{N})$ adalah untuk merangsang pertumbuhan tanaman secara keseluruhan, terutama pada fase vegetatif, khususnya batang, cabang, dan daun. Selain itu, nitrogen pun berperan penting dalam pembentukan hijau daun (klorofil) yang sangat berguna dalam proses fotosintesis. Fungsi lainnya ialah membentuk protein, lemak, dan berbagai persenyawaan organik lainnya. Unsur fosfor (P) bertugas mengedarkan energi keseluruh bagian tanaman, berguna untuk merangsang pertumbuhan dan perkembangan akar, khususnya akar benih dan tanaman muda. Selain itu, fosfor juga berfungsi sebagai bahan mentah untuk pembentukan sejumlah protein tertentu, membantu asimilasi dan pernapasan, mempercepat pembungaan dan pembuahan, serta mempercepat pemasakan biji dan buah.

$\mathrm{P}$ dibutuhkan tanaman dalam jumlah relatif besar, sedikit lebih kecil dibawah $\mathrm{N}$ dan K, setara dengan S, Ca dan Mg. Fosfat: unsur P sangat reaktif, di alam ditemukan dalam bentuk gugus fosfat, ATP: transfer energi, NADP: fotosintesis, Asam nukleat: bahan DNA, RNA, dan Lemak fosfat (phospholipids): membran sel dan organ dalam sel. Unsur fosfor (P) memiliki sifat mobilitas dalam tanaman, mudah dipindahkan dari bagian daun yang tua ke titik tumbuh. Gejala klorosis: tanaman kerdil, pertumbuhan akar buruk, kedewasaan terlambat, warna daun hijau kelam, muncul warna keunguan misalnya pada jagung. Jika $\mathrm{P}$ berlebihan meskipun tidak secara langsung meracuni tanaman, akan menyebabkan merangsang pertumbuhan organisme perairan, mempercepat eutrofikasi, $\mathrm{P}$ tanah yang berlebih meningkatkan pengangkutan $\mathrm{P}$ dalam sedimen, air limpasan.

Kalium merupakan unsur ketiga yang penting setelah N dan P. Kalium berfungsi antara lain untuk meningkatkan proses fotosintesis, mengefisienkan penggunaan air, mempertahankan turgor, membentuk batang yang lebih kuat, sebagai aktivator bermacam sistem enzim, memperkuat perakaran sehingga tanaman lebih tahan rebah dan meningkatkan ketahanan tanaman terhadap penyakit. Meskipun pada kenyataannya total $\mathrm{K}$ yang diserap oleh tanaman lebih besar daripada $\mathrm{N}$ maupun $\mathrm{P}$, namun demikian perhatian mengenai kalium sampai saat ini masih kurang dibandingkan kedua unsur tersebut. Tanaman menyerap kalium dalam bentuk ion $\mathrm{K}^{+}$. Kalium di dalam tanah ada 
dalam berbagai bentuk, yang potensi penyerapannya untuk setiap tanaman berbeda-beda. Ion-ion $\mathrm{K}^{+}$di dalam air tanah dan ion-ion $\mathrm{K}^{+}$yang di adsorpsi, dapat langsung diserap. Di samping itu tanah mengandung juga persediaan mineral tertentu dalam bentuk berbagai macam silikat, dimana kalium membebaskan diri sebagai akibat dari pengaruh iklim. Persediaan mineral dalam bentuk kalium ini terutama penting bagi tanah liat dari laut yang masih muda. Bertambah banyak persediaan ini di dalam tanah, maka akan lebih banyak pula kalium di bebaskan sebagai akibat dari pengaruh iklim yang diserap oleh tanaman.

\section{KESIMPULAN}

1. Cara pembuatan pupuk kompos padat berbahan dasar limbah organik pasar Mardika cukup sederhana, yaitu dengan menambahkan EM4 sebagai biang mikroorganisme yang berfungsi sebagai pengurai bahan organik menjadi lebih sederhana sehingga mudah diserap oleh tanaman. Bahan organik padat berupa sampah diperam selama 34 minggu dalam kondisi aerob sampai suhu fermentasi turun menjadi $27^{\circ} \mathrm{C}$ dan bahan organik menjadi warna coklat kehitaman.

2. Cara pembuatan pupuk organik cair sama halnya dengan pembuatan pupuk organik padat. Bagian cair merupakan filtrat atau residu cairan pada hasil fermentasi pupuk organik padat yang tersaring pada dasar tabung fermentor.

3. Kualitas fisik pupuk organik padat berbahan dasar limbah sampah pasar Mardika memiliki struktur yang remah, berwarna coklat sampai hitam, memiliki suhu akhir berkisar antara $27^{\circ} \mathrm{C}$ sampai $30^{\circ} \mathrm{C}$, sedangkan kualitas fisik pupuk organik cair adalah memiliki warna coklat dengan suhu akhir adalah $27^{\circ} \mathrm{C}$ dan memiliki aroma khas.

4. Pupuk organik padat dan cair berbahan dasar sampah dari pasar mardika dengan perlakuan penambahan konsentrasi EM4 memiliki kandungan nitrogen, posfor, dan kalium yang cukup tinggi. Kadar N, P, dan K tertinggi diperoleh pada perlakuan EM4 $25 \%$ dan terendah pada perlakuan EM4 5\%.

\section{SARAN}

1. Sampah organik berupa sisa sayur dan buah dari pasar mardika dapat diubah menjadi pupuk organik cair dan padat dengan melakukan penambahan EM4 sebagai biang mikroorganisme yang membantu dalam proses fermentasi. Olehnya itu disarankan agar masyarakat dapat menggunakan limbah organik pasar dalam pembuatan pupuk organik padat maupun cair

2. Penambahan EM4 pada konsentrasi $25 \%$ sangat baik dalam meningkatkan kadar N, $\mathrm{P}$, dan $\mathrm{K}$ dari pupuk organik padat maupun organik cair berbahan dasar limbah pasar Mardika Ambon. Olehnya itu, disarankan kepada peneliti selanjutnya atau masyarakat agar menggunakan konsentrasi EM4 25\% dalam membuat pupuk organik padat maupun cair berbahan dasar limbah pasar 
3. Disarankan bagi peneliti selanjutnya untuk melakukan peneliti yang sama dengan meningkatkan konsentrasi EM4 dan mengamati variabel lain selain yang telah diteliti oleh peneliti sebelumnya.

\section{DAFTAR PUSTAKA}

Cattelan, A.J., P.G. Hartel, and J.J. Fuhrmann. 1999. Screening for plant growthpromoting rhizobacteria to promote early soybean growth. Soil Sci.Soc. Am.J. 63: 1.670-1.680.

FNCA Biofertilizer Project Group. 2006. Biofertilizer Manual. Forum for Nuclear Cooperation in Asia (FNCA). Japan Atomic Industrial Forum. Tokyo.

Glick, B.R. 1995. The Enhancement of Plant Growth by Free-Living Bacteria. J. Microbial. 4: 109-117.

Honcamp, F. 1931. Historisches über die Entwicklung der Pflanzenernährungslehre, Düngung und Düngemittel. In F. Honcamp (Ed.). Handbuch der Pflanzenernährung und Düngelehre, Bd. I und II. Springer, Berlin.

Jutono. 1982. The application of Rhizobium-inoculant on soybean in Indonesia. Ilmu Pertanian. Agric. Sci. 3(5): 215-222.

Kloepper, J.W. 1993. Plant growth-promoting rhizobacteria as biological control agents.

p. 255-274. In F.Blaine Metting, Jr. (Ed.). Soil Microbiology Ecology, Applications in Agricultural and Environmental Management. Marcel Dekker, Inc., New York.

Kloepper, J.W., R.M. Zablotowicz, E.M. Tipping, and R. Lifshitz. 1991. Plant growth promotion mediated by bacterial rhizosphere colonizers. p. 315-326. In D.L. Keister and P.B. Cregan (Eds.). The Rhizosphere and Plant Growth. Kluwer Academic Pub., Dordrecht.

Macdonald, 1989. An overview of crop inoculation, p. 1-9. In R.Campbell and R.M. Macdonald (Eds). Microbial Inoculation of Crop Plants. IRL Press. Oxford.

Nan Djuarnani, Kristian dan Budi Susilo Setiawan. 2006. Cara Cepat Membuat Kompos. AgroMedia Pustaka. Jakarta

Purwasasmita, M. 2009. Mikroorganisme Lokal Sebagai Pemicu Siklus Kehidupan Dalam Bioreaktor Tanaman. Seminar Nasional Teknik Kimia Indonesia, 19-20 Oktober 2009

Redaksi AgroMedia. 2008. Cara Praktis Membuat Kompos. AgroMedia Pustaka. Jakarta Saraswati, R., D.H. Goenadi, D.S. Damardjati, N. Sunarlim, R.D.M. Simanungkalit, dan Djumali Suparyani. 1998. Pengembangan Rhizo-plus untuk Meningkatkan Produksi, Efisiensi Pemupukan Menunjang Keberlanjutan Sistem Produksi Kedelai. Laporan Akhir Penelitian Riset Unggulan Kemitraan I Tahun (1995/1996-1997-1998). Balai Penelitian Bioteknologi Tanaman Pangan. 
Sebayang, K. dan D.A. Sihombing 1987. The technology impact on soybean yield in Indonesia. pp. 37-48. In J.W.T. Bottema, F. Dauphin, and G. Gijsbers (Eds.). Soybean Research and Development in Indonesia. CGPRT Centre. Bogor.

Simanungkalit, R.D.M and R. Saraswati 1993. Application of biotechnology on biofertilizer production in Indonesia. pp. 45-57. In S. Manuwoto, S. Sularso, and K. Syamsu (Eds.). Proc. Seminar on Biotechnology: Sustainable Agriculture and Alternative Solution for Food Crisis. PAU-Bioteknologi IPB. Bogor.

Sofian. 2006. Sukses Membuat Kompos dari Sampah. AgroMedia Pustaka. Jakarta.

Subba Rao, N.S. 1982. Biofertilizer in Agriculture. Oxford and IBH Publishing Co. New Delhi.

Toxopeus, H.J. 1938. Over het voorkomen van de knolltjesbacterien van kedelee in verband met de wenschelijk van enten van het zaaizaad. Landbouw 14: 197-217. 